\title{
Crustacean zooplankton communities in 13 lakes of Yunnan-Guizhou plateau: Relationship between crustacean zooplankton biomass or size structure and trophic indicators after invasion by exotic fish
}

\author{
Nichun Guo, Min Zhang, Yang Yu, Shanqing Qian, Daming Li and Fanxiang Kong* \\ State Key laboratory of Lake Science and Environment, Nanjing Institute of Geography and Limnology, Chinese Academy \\ of Sciences, Beijing East Road 73, Nanjing 210008, P. R. China
}

Received 2nd June 2009; Accepted 30 July 2009

\begin{abstract}
We investigated crustacean zooplankton communities and their relationships to environmental factors in 13 lakes of Yunnan-Guizhou plateau to determine whether there is a consistent relationship between trophic indicators and crustacean zooplankton biomass or size structure. The lakes showed a wide range of trophic status, with total phosphorus (TP) ranging from 0.013 to $0.268 \mathrm{mg} . \mathrm{L}^{-1}$, and chlorophyll $a$ from 0.9 to $76.26 \mu \mathrm{g} . \mathrm{L}^{-1}$. Continuous stocking with exotic planktivorous fish had taken place on a wide scale in these plateau lakes. About 36 species of Crustacea were found, of which Cladocera were represented by 20 taxa (12 genera), and Copepoda by 16 taxa (13 genera). Canonical correspondence analysis partitioned these species into two clusters. Physicochemical features and food-webs of different lakes seemed to be the key factors determining zooplankton species composition and distribution patterns. Between the 13 lakes, there was no significant relationship between cladocerans and chlorophyll $a$ suggesting phytoplankton biomass was little controlled by macrozooplankton. The positive correlation between chlorophyll $a$ and copepods suggested the high copepods biomass or size structure caused by the invasion of exotic planktivorous fish had a negative effect on water quality.
\end{abstract}

Key words: Zooplankton communities / CCA / cladocerans / copepods

\section{Introduction}

Crustacean zooplankton species composition and distribution patterns have been studied from oligotrophic to hypertrophic lakes over the last fifty years (Hairston et al., 1960; Patalas, 1971; Amarasinghe et al., 1997; Swadling et al., 2000). Previous studies have investigated zooplankton species composition, abundances and their interactions with environmental factors (Elser and Goldman, 1991; Currie et al., 1999). Other studies have related crustacean biomass and size structure to trophic indicators in different lakes (Pace, 1986; Taylor and Carter, 1997; Wang et al., 2007b). Although particular species have been suggested as good indicators for trophic status (Attayde and Bozelli, 1998), major crustacean zooplankton groups respond differently to trophic conditions (Benndorf et al., 2002; Pinto-Coelho et al., 2005). Different relationships between zooplankton and tropic status have been attributed to the

\footnotetext{
*Corresponding author: fxkong@niglas.ac.cn
}

different physical-chemical features (Tessier and Horwitz, 1990). Ecological processes and food-webs in different lakes can also greatly influence the relationships (Mazumder, 1994; Havens, 2002; Auer et al., 2004).

A mechanistic understanding of the ecological processes and food-web is necessary to explain the interactions between the zooplankton community and trophic indicators (Elser and Goldman, 1991). Hypotheses for studying the food-web for the management of reservoirs and lakes (Hairston et al., 1960; Benndorf et al., 2002), include the "Cascading Trophic Interactions" hypothesis (Carpenter et al., 1985) and the "bottom-up: top-down" hypothesis (McQueen et al., 1986). Many studies emphasize the "top-down" forces on phytoplankton biomass, suggesting significant influence by the biomass and size structure of herbivorous cladocerans (Brooks and Dodson, 1965; McCauley and Kalff, 1981; Stemberger and Miller, 2003; Wang et al., 2007b). In order to reduce the phytoplankton biomass and improve water quality, a lower biomass of planktivorous fish is necessary to allow 
high macrozooplankton biomass in mesotrophic and slightly eutrophic lakes (Shapiro et al., 1975; Carpenter et al., 1985; Benndorf, 1987).

Since the 1950s, exotic planktivorous fish have been found and studied in all 13 lakes of Yunnan-Guizhou plateau (Xie and Chen, 2001). Two planktivorous fish, bighead and silver carp, were introduced to Lake Xingyun in the early 1950s for the purpose of aquaculture (Xie and Chen, 2001), and another planktivorous fish, Neosalanx taihuensis, was introduced to Lake Xingyun and Lake Dianchi in the 1980s for the same purpose (Zhuang et al., 1996). A high production of $N$. taihuensis was soon observed in many lakes of this plateau (Zhuang et al., 1996). Introduction of exotic planktivorous fish has led to significant ecological consequences in the lake ecosystems (Zhang et al., 2005). However, little is known about the relationship between the crustacean zooplankton community and water quality after invasion by exotic fish (Zhang et al., 2005). Mehner et al. (2008) found a strong correlation between planktivorous fish and the proportion of copepods in the crustacean zooplankton community. Liu (2001) also found the high grazing pressure of $N$. taihuensis led to an obvious reduction in the abundance of small bodied calanoids, with an increase in the abundance of a large bodied calanoid Neodiaptomus schmackeri (Z.R. Wang, private communication). The increase of copepod biomass and change in size structure caused by the invasion of planktivorous fish in these lakes would alter the lake ecosystems to some extent and may influence water quality.

The 13 lakes of this study, located in southwest China, are mainly mesotrophic or slightly eutrophic (Liu, 2001; Zhang et al., 2005). A deep water refuge for crustacean zooplankton (Wissel et al., 2000) is available in most of these lakes. This may induce a top-down control on phytoplankton biomass. The main goals of our study were twofold: First, to present a snapshot of crustacean zooplankton communities and their relationship to environmental factors in these lakes. Second, to test whether there is a consistent relationship between the biomass or size of crustaceans and trophic state among lakes with similar trophic conditions, after invasion by exotic fish.

\section{Material and methods}

\section{Study site}

A total of 13 lakes, located in southwest China, were selected for this study (Table 1). These lakes ranged from 10.7 to $297.9 \mathrm{~km}^{2}$ in area and from 5 to $155 \mathrm{~m}$ in maximum lake depth. Secchi disk visibility (SD) measured in summer varied from 0.36 to $10.06 \mathrm{~m}$. Temperature in winter ranged from 13.0 to $15.8{ }^{\circ} \mathrm{C}$, with an average of $15.2{ }^{\circ} \mathrm{C}$, and in summer, from 18.4 to $26.6{ }^{\circ} \mathrm{C}$, with an average of $21.9^{\circ} \mathrm{C}$. Total phosphorus (TP) ranged from 0.013 to $0.268 \mathrm{mg} . \mathrm{L}^{-1}$ and chlorophyll $a(\mathrm{Chl} a)$ from 0.9 to $76.26 \mu$ g.L ${ }^{-1}$ (Fig. 1).

\section{Sampling and sample processing}

Water sampling at 3-7 stations in each of the 13 lakes was conducted in November 2007 and July 2008 (Tables 1 and 2). Zooplankton samples were taken during daylight hours from near the lake bottom to the surface using a modified 5-L Patalas sampler. Quantitative samples of crustaceans were collected by sieving 10 or $20 \mathrm{~L}$ water samples through a $64 \mu \mathrm{m}$ plankton net and were stored in $50 \mathrm{~mL}$ plastic bottles fixed with $5 \%$ formalin solution. In addition, a 112- $\mu \mathrm{m}$ plankton net was used through the water column to collect qualitative samples for species identification. Crustaceans were identified to species level and counted using a compound microscope (at a magnification of $100 \times)$. Cladocera were identified according to Chiang and Du (1979), and Copepoda according to Shen (1979). Wet weights of crustacean zooplankton were estimated according to the weight-body size regression of Huang (1999). Cladocera were measured from the top of the head to the base of the tail spine. Copepoda were measured from the top of the head to the end of the furca. Species comprising more than $5 \%$ of the total crustacean abundance were considered as 'dominants'.

For measurement of $\mathrm{Chl} a$ and nutrient concentrations, we combined water sampled from the water surface and the bottom. Total nitrogen (TN) was measured by alkaline potassium persulfate oxidation and absorbance measured at $220 \mathrm{~nm}$. After oxidation with potassium persulfate under pressure, the ammonium molybdate method was used to analyze total phosphorus (TP). The Nessler colorimetry method was used to analyze Ammonium-N $\left(\mathrm{NH}_{4}{ }^{+}\right)$. The automated Korolev/cadmium reduction method was used to analyze nitrate $\left(\mathrm{NO}_{3}{ }^{-}\right)$. All of the above methods are described in detail in Huang (1999). Each lake was sampled at least twice yearly, but only data from winter and summer were analyzed in the present study.

\section{Statistical analysis}

Canonical correspondence analysis (CCA) was used to partition lake groups and to analyze the relationship between species distribution patterns and environmental factors. All data were analyzed using the CANOCO 4.53 package (Ter Braak, 2004). Correlation analysis was used to demonstrate the relationship between crustacean biomass and trophic indicators, using SPSS 10.0. The data were tested for normality with the Kolmogorov-Smirnov one-sample test and $\log _{10}$-transformed before analysis. Only those taxa which were considered as 'dominants' in more than $10 \%$ of the 13 lakes were included in the crustacean species data matrix (11 of the 36 enumerated taxa). A set of explanatory variables was created, which contained all measured environmental factors (lake depth, area, dissolved oxygen (DO), Secchi disk visibility (SD), $\mathrm{pH}, \mathrm{TN}, \mathrm{TP}, \mathrm{TN} / \mathrm{TP}, \mathrm{Chl} a$ and temperature). The original data were used for the partitioning of lake groups. After a forward selection and down weighting of rare species, final variables were obtained by CCA. The crustacean 
Table 1. Limnological characteristics of the studied lakes.

\begin{tabular}{|c|c|c|c|c|c|c|c|c|}
\hline Lakes & Samples & Area $\left(\mathrm{km}^{2}\right)$ & Depth (m) & $\mathrm{SD}(\mathrm{m})$ & $\mathrm{pH}$ & $\mathrm{TN}\left(\mathrm{mg} \cdot \mathrm{L}^{-1}\right)$ & TP (mg.L $\left.{ }^{-1}\right)$ & Chl $a\left(\mu \mathrm{g} . \mathrm{L}^{-1}\right)$ \\
\hline Dianchi & 5 & 297.9 & 5.87 & 0.56 & 9.18 & 3.13 & 0.138 & 58.78 \\
\hline Fuxian & 5 & 211 & 155 & 4.35 & 8.87 & 0.85 & 0.025 & 3.32 \\
\hline Xingyun & 4 & 34.7 & 11 & 0.81 & 8.67 & 2.30 & 0.181 & 45.68 \\
\hline Yangzonghai & 3 & 31.7 & 30 & 2.62 & 9.22 & 0.77 & 0.058 & 2.17 \\
\hline Qilu & 3 & 36.9 & 6.8 & 1.10 & 8.34 & 3.65 & 0.069 & 42.24 \\
\hline Yilong & 3 & 38 & 6.2 & 0.95 & 9.17 & 1.62 & 0.048 & 13.54 \\
\hline Erhai & 7 & 249 & 20.7 & 1.38 & 8.40 & 0.81 & 0.045 & 9.81 \\
\hline Caohai & 3 & 25 & 5 & 1.23 & 8.87 & 0.78 & 0.034 & 5.40 \\
\hline Datunhai & 3 & 12.3 & 5 & 0.37 & 9.20 & 2.43 & 0.268 & 76.26 \\
\hline Changqiaohai & 3 & 10.7 & 5.5 & 0.60 & 9.48 & 3.07 & 0.055 & 33.48 \\
\hline Chenghai & 7 & 77.2 & 35.1 & 1.42 & 9.34 & 0.86 & 0.041 & 9.38 \\
\hline Qionghai & 5 & 31 & 34 & 1.32 & 7.41 & 0.61 & 0.029 & 2.95 \\
\hline Lugu & 5 & 48.5 & 93.5 & 10.06 & 8.39 & 0.17 & 0.013 & 0.90 \\
\hline
\end{tabular}
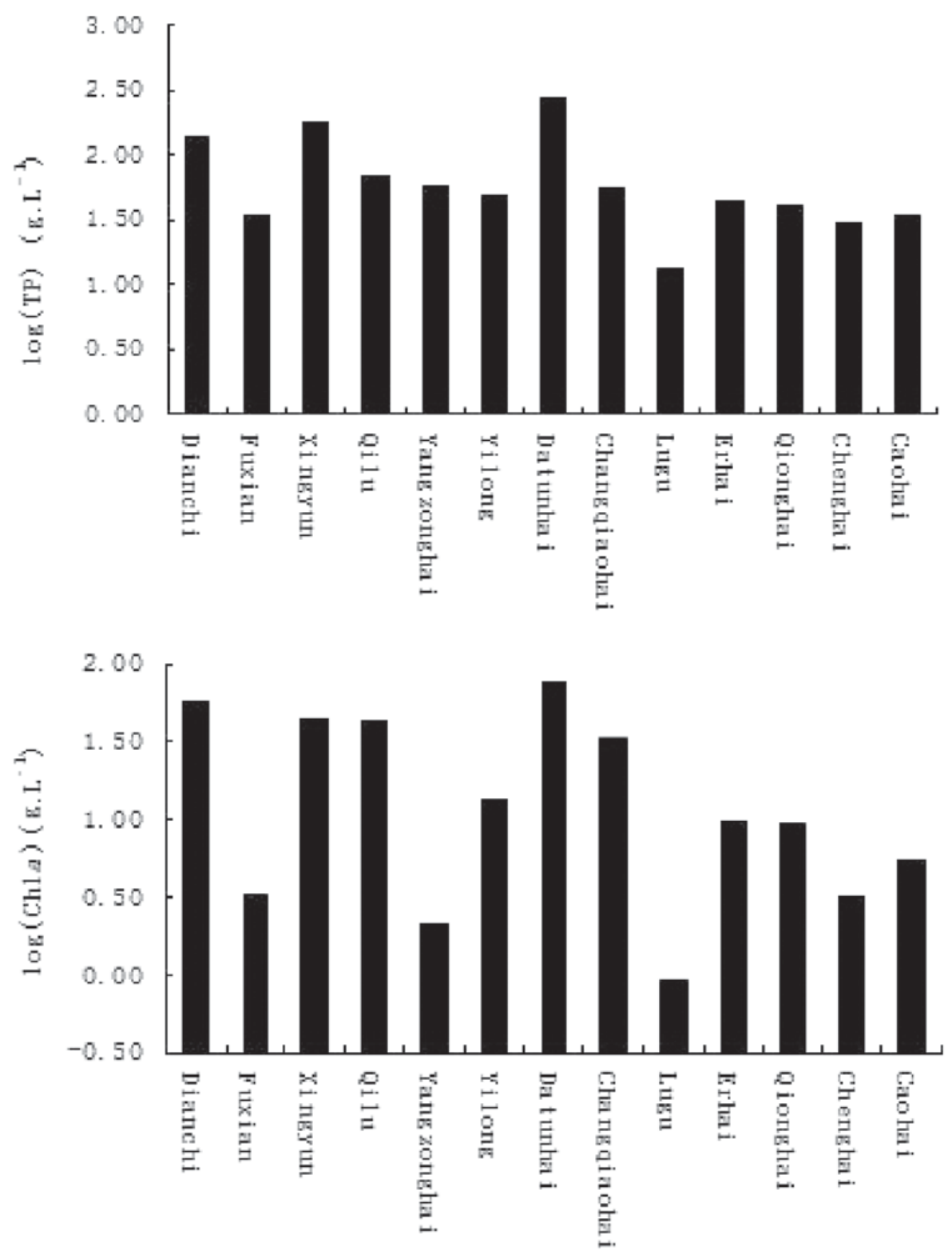

Fig. 1. Total phosphorus (TP) and chlorophyll $a(\mathrm{Chl} a)$ in the 13 lakes during the summer sampling (from June 18 to August 6 ). 
Table 2. Production of Neoslanx taihuensis in different lakes (t/a).

\begin{tabular}{|c|c|c|c|c|c|c|c|}
\hline Year & Dianchi & Xingyun & Fuxian & Qilu & Erhai & Chenghai & Total \\
\hline$\overline{1980}$ & 0.5 & & & & & & 0.5 \\
\hline 1981 & 6.5 & & & & & & 6.5 \\
\hline 1982 & 1200 & & & & & & 1200 \\
\hline 1983 & 2000 & & & & & & 2000 \\
\hline 1984 & 3500 & & & & & & 3500 \\
\hline 1985 & 360 & 78 & & & & & 438 \\
\hline 1986 & 2200 & 200 & & & & & 2400 \\
\hline 1987 & 3203 & 400 & 70 & & & & 3673 \\
\hline 1988 & 2300 & 400 & 190 & & & & 2691 \\
\hline 1989 & 2500 & 300 & 334 & & & & 3134 \\
\hline 1990 & 1100 & 100 & 1155 & & & & 2355 \\
\hline 1991 & 500 & 405 & 963 & & 500 & 3 & 2371 \\
\hline 1992 & 355 & 420 & 1181 & 50 & 750 & 48 & 2804 \\
\hline 1993 & 400 & 350 & 1313 & 20 & 250 & 400 & 2733 \\
\hline 1994 & 200 & - & - & - & - & 580 & 780 \\
\hline
\end{tabular}

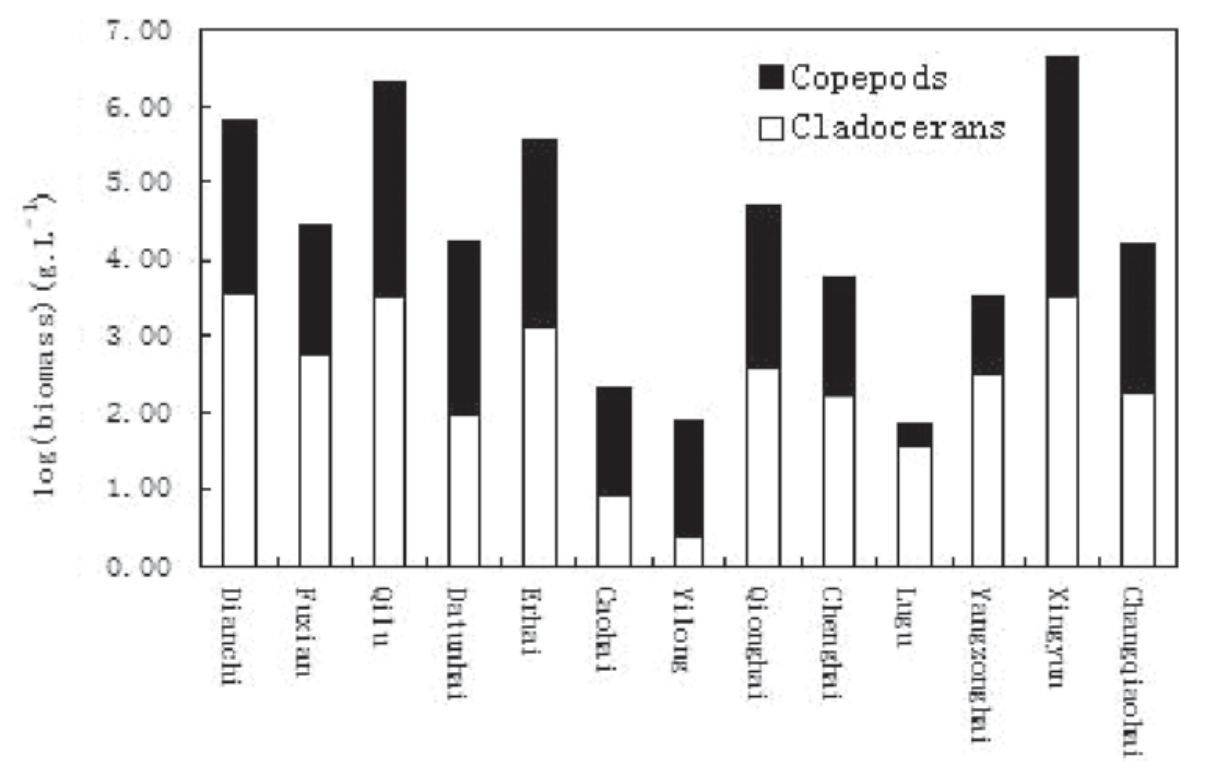

Fig. 2. Biomass composition of crustacean zooplankton in summer in the 13 lakes.

abundances and environmental variables were $\log (x+1)$ transformed before analysis to obtain normality of variance in the datasets.

\section{Results}

\section{Crustacean zooplankton community and species dominance}

Crustacean zooplankton communities were quite different between winter and summer. In winter, the community was mainly composed of D. hyalina, B. coregoni, $C$. vicinus and $S$. dorrii. In summer, the community was mainly composed of $B$. coregoni, $C$. sphaericus, $T$. taihokuensis and $P$. tunguidus. From oligotrophic to hypertrophic lakes, the diminishing significance of large herbivorous cladocerans (Daphnia) was accompanied by the increasing predominance of cyclopoids (Cyclops, Thermocyclops) and small cladocerans (Chydorus, Bosmina). Crustacean zooplankton species composition, frequency of occurrence and percentage as a dominant in the 13 lakes are shown in Table 1. About 36 taxa were identified. Cladocera were represented by 20 taxa (12 genera) and Copepoda by 16 taxa (13 genera). Of the 36 species, about $60 \%$ were littoral species of low abundance. The most common species were B. coregoni, $C$. sphaericus and T. taihokuensis. They were found in $85 \%, 60 \%$ and $63 \%$, respectively, of all the lakes sampled. E. serrulatus, T. taihokuensis, B. coregoni and D. hyalina occurred in $25-85 \%$ of these lakes. None of the remaining species occurred in more than $25 \%$ of these lakes. The following species dominated the crustacean plankton of the lakes sampled: B. coregoni (17\% of total abundance), 
Table 3. Zooplankton species, frequency of occurrence (F) and percentage as a dominant (D) (>5\% of the total crustacean density) in the 13 lakes.

\begin{tabular}{|c|c|c|c|c|c|}
\hline Species & $\mathrm{F}(\%)$ & $\mathrm{D}(\%)$ & Species & $\mathrm{F}(\%)$ & $\mathrm{D}(\%)$ \\
\hline Chydorus sphaericus & 60 & 10 & Acroperus harpae & 5 & 0 \\
\hline Daphnia hyalina & 48 & 14 & Bosminopsis & 5 & 0 \\
\hline Diaphanosoma brachyurun & 28 & 5.2 & Sinocalanus dorrii & 5 & 0 \\
\hline Simocephalus vetulus & 8 & 0 & Schmackeria forbesi & 5 & 0 \\
\hline Simocephalus spp. & 5 & 0 & Neodiaptomus mariadvigae mariadvigae & 20 & 1.3 \\
\hline Bosmina coregoni & 85 & 17 & Neodiaptomus yangtsekiangensis & 31 & 3.4 \\
\hline Ceriodaphnia pulchella & 15 & 4.2 & Neutrodiaptomus alatus & 5 & 0 \\
\hline C. quadrangula & 25 & 17.5 & Tropodiaptomus oryzanus & 2 & 0 \\
\hline C. cornuta & 9 & 0 & Cyclops vicinus & 9 & 6.5 \\
\hline C. hamata & 9 & 0 & Thermocyclops taihokuensis & 63 & 11.5 \\
\hline Moina macrocopa & 9 & 0 & Thermocyclops hyalinus & 31 & 10.3 \\
\hline Moina spp. & 6 & 0 & Eodiaptomus sinensis & 2 & 0 \\
\hline Pleuroxus & 9 & 0 & Eucylops serrulatus & 29 & 18.1 \\
\hline Scapholeberis mисronata & 5 & 0 & Eucylops euacanthus & 8 & 0 \\
\hline Daphnia cucullata & 6 & 0 & Elaphoidella & 6 & 0 \\
\hline Alona & 5 & 0 & Phyllodiaptomus tunguidus & 22 & 16.7 \\
\hline Daphnia longispina & 11 & 0 & Paracyclops affinis & 11 & 0 \\
\hline Daphnia pulex & 2 & 0 & Sinodiaptomus sari & 15 & 2.1 \\
\hline
\end{tabular}

D. brachyurum $(5.2 \%)$, T. taihokuensis $(11.5 \%), \quad$. serrulatus $(18.1 \%)$, C. vicinus $(6.5 \%)$ and $P$. tunguidus $(16.7 \%)$. The biomass of cladocerans and copepods both showed a wide range in summer, with small cladocerans being dominant in most of the lakes (Fig. 2, Table 3).

The two-dimensional plot of CCA partitioned the species into two clusters (Fig. 3a). The physicochemical variables explained $82.1 \%$ of the total variance of species distribution (Table 4). Species in cluster I included: D. hyalina, B. coregoni, E. serrulatus, T. hyalinus and C. sphaericus; species in cluster II included: T. taihokuensis, $C$. vicinus and D. brachyurun. The two clusters showed different preference for trophic state and physical conditions (Fig. 3a). B. coregoni, C. sphaericus peaked in lakes with relatively high nutrient loading, low SD and shallow depth, while $C$. vicinus and $D$. brachyurun usually peaked in deeper lakes with low trophic state and low SD. In addition, the biplot of the CCA analysis showed that cladocerans like B. coregoni, C. sphaericus deviated from the calanoids ( $N$. yangtsekiangensis, $P$. tunguidus), but predatory cyclopoids ( $T$. hyalinus and $E$. serrulatus) peaked with them. Moreover, $\mathrm{pH}$ seemed to be an important factor determining the dominance of C. vicinus, and D. brachyurun.

\section{Relationship between crustacean zooplankton and trophic indicators}

The biomass of crustacean zooplankton in the 13 lakes ranged from 34.39 to $4554.39 \mu \mathrm{g} . \mathrm{L}^{-1}$, the average being $1234.33 \mu \mathrm{g} . \mathrm{L}^{-1}$ (Fig. 2). The crustacean biomass showed a weak correlation with the trophic indicators Chl $a$ $\left(\mathrm{r}^{2}=0.21, P<0.05\right)$ and TP $\left(\mathrm{r}^{2}=0.15, P<0.05\right)$ (Fig. 4). The mean body length of crustacean zooplankton (including copepod nauplii) in the lakes ranged from 0.248 to $0.553 \mathrm{~mm}$, the overall average for zooplankton being $0.348 \mathrm{~mm}$. The mean body length of crustacean zooplankton showed no correlation with $\mathrm{Chl} a\left(\mathrm{r}^{2}=0.02, P>0.05\right)$ or TP $\left(\mathrm{r}^{2}=0.01, P>0.05\right)$. The largest animals in our samples were $D$. hyalina, found in winter, always being greater than $1 \mathrm{~mm}$ in body length. The most abundant crustaceans were mainly omnivorous, such as B. coregoni and $T$. taihokuensis. Biomass of cladocerans did not show significant correlations with $\mathrm{Chl} a\left(\mathrm{r}^{2}=0.03\right.$, $P>0.05)$ or TP $\left(\mathrm{r}^{2}=0.04, P>0.05\right)$. However, biomass of copepods showed significant correlations with Chl $a$ $\left(\mathrm{r}^{2}=0.46, P=0.000\right)$ and TP $\left(\mathrm{r}^{2}=0.25, P<0.05\right)($ Fig. 5$)$. In all 13 lakes, Chl $a$ and TP were strongly correlated in summer $\left(r^{2}=0.72, P=0.000\right)$, suggesting that phytoplankton biomass was mainly controlled by nutrient resources, with crustacean zooplankton having a minor effect.

Between the two types of lakes (Group I and Group II) (Fig. 3b), mean body length of crustacean zooplankton was $0.368 \mathrm{~mm}$ and $0.327 \mathrm{~mm}$, TP was 0.111 and $0.053 \mathrm{mg} . \mathrm{L}^{-1}$, and Chl $a$ was 26.93 and $19.37 \mu \mathrm{g} . \mathrm{L}^{-1}$, respectively. A significant relationship between copepods and cladocerans was found in the Lake Group II. Copepod biomass of Lake Group II was positively related to cladoceran biomass $\left(\mathrm{r}^{2}=0.65, P=0.000\right)$, and to cladoceran size structure $\left(\mathrm{r}^{2}=0.76, P=0.000\right)$. In summer, the mean body length of copepods was also positively related to cladoceran biomass $\left(\mathrm{r}^{2}=0.36\right.$, $P=0.000)$ and to cladoceran size structure $\left(\mathrm{r}^{2}=0.42\right.$, $P=0.000$ ) (Fig. 6). The mean body length of copepods was positively related to $\mathrm{Chl} a\left(\mathrm{r}^{2}=0.16, P<0.05\right)$ and TP $\left(\mathrm{r}^{2}=0.61, P=0.000\right)$ (Fig. 7). We examined the effect of crustacean zooplankton biomass on water quality indicators, and found that copepod biomass in Lake Group II had a significant effect on the Chl $a$ and SD (Table 5). 

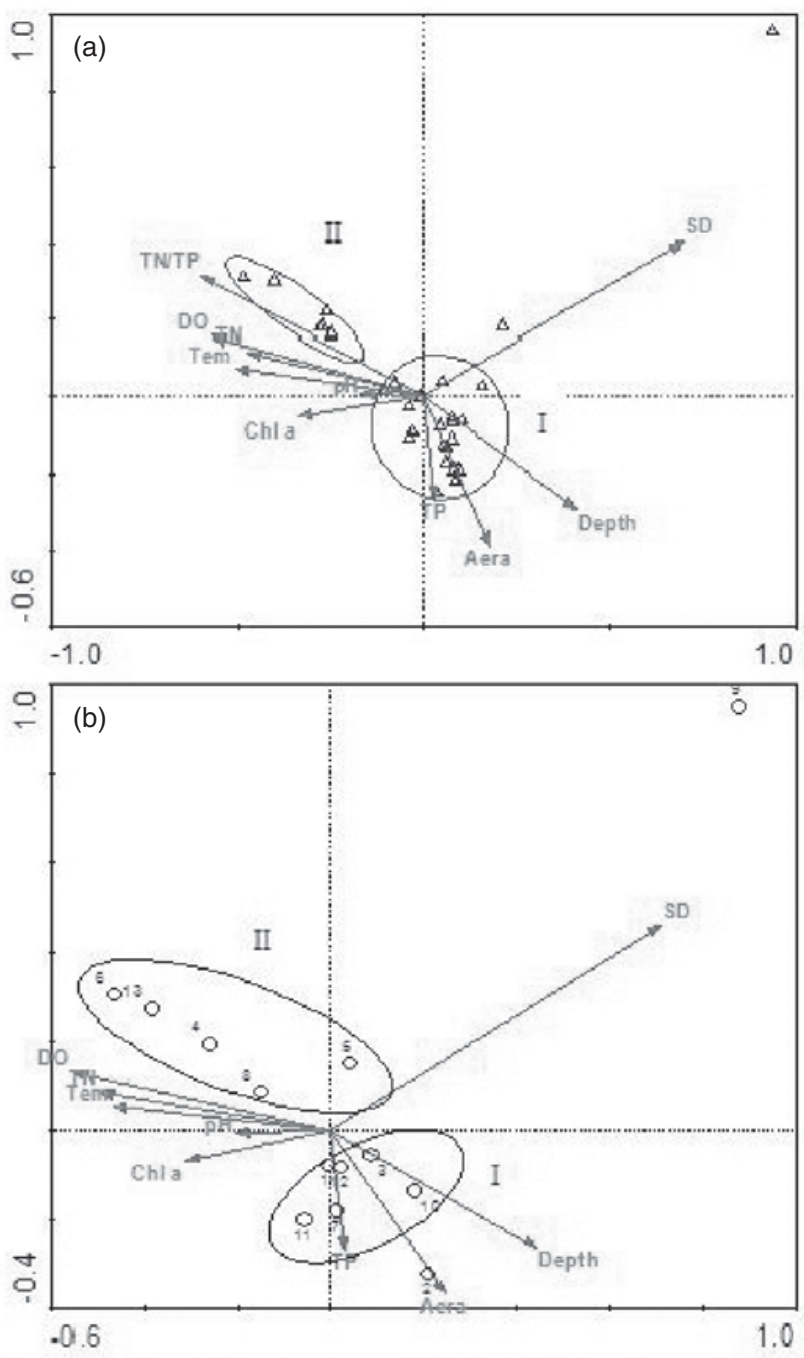

Fig. 3. Biplot of the first two axes of CCA analysis for (a) species association with the environmental factors. Cluster I in (a) includes: C. sphaericus, D. hyalina, T. hyalinus, E. serrulatus, B. coregoni. Cluster II includes: T. taihokuensis, D. brachyurum, C. vicinus (b) partition of lake groups. Lake group I in (b) including: 1) Dianchi, 3) Xingyun, 7) Datunhai, 10) Chenghai, 11) Qionghai, 12) Erhai. Lake group II in (b) including: 4) Yilonghu, 5) Yangzonghai, 6) Qiluhu, 8) Changqiaohai, 13) Caohai.

\section{Discussion}

\section{Crustacean zooplankton taxonomic structure}

Swadling et al. (2000) reported that lakes in forested catchments were generally deep, and cladocerans in these lakes were mainly composed of Daphnia and Bosmina. These genera have a great significance in terms of occurrence and biomass in our study lakes and are common in temperate and tropical water bodies (Arcifa, 1984; Gulati, 1990; Pinto-Coelho et al., 2005). With respect to community structure, cyclopoids (Cyclops) and cladocerans (Daphnia and Bosmina) dominated slightly eutrophic lakes (Patalas, 1971), while calanoids (Phyllodiaptomus) and cladocerans (Bosmina) dominated oligotrophic lakes (Zhang et al., 2005). In the present study, Daphnia was only dominant in five lakes during winter. The three dominant cladocerans had relatively high occurrence and dominance in this study, despite possible predation by other invertebrates (Blumenshine and Hambright, 2003). According to the PEG-model (Sommer et al., 1986), temperature, food resources and fish predation explain the structure of zooplankton communities. Studies have shown that Bosmina and Ceriodaphnia to be inefficient consumers of phytoplankton biomass, while Daphnia are efficient phytoplankton consumers in many lakes (Brooks and Dodson, 1965; Benndorf et al., 2002). On the other hand, predation by cyclopoid copepods would result in great mortality of herbivorous zooplankton (Blumenshine and Hambright, 2003). The biplot of the CCA analysis showed that cladocerans like $B$. coregoni and $C$. sphaericus deviated from the calanoids ( $N$. yangtsekiangensis, P. tunguidus), while the small predatory invertebrates, T. hyalinus and E. serrulatus, peaked with them. Thus, disappearance of Daphnia and the increasing dominance of invulnerable copepods might be an outcome of combined predation by large predatory invertebrates and planktivorous fish.

In the present study, the measured environmental factors explained $82.1 \%$ of the total variance of crustacean species distribution, suggesting that environmental factors within lakes are important in structuring the crustacean community. Factors such as bacteria (Havens, 2002), the invertebrate Chaoborus (Benndorf et al., 2000; Wissel et al., 2000), and planktivorous fish in the food web (Havens, 2002; Wang et al., 2007a) also partly explained variance of crustacean species distribution.

\section{Response of crustacean biomass and size structure to water quality indicators}

Compared with the crustacean zooplankton biomass found in shallow lakes by Wang et al. (2007a), the mean biomass of crustacean zooplankton in these 13 lakes was higher. The probable explanation is that the deep water in these lakes provides refuges for crustacean zooplankton (Wissel et al., 2000). The mean body length of crustacean zooplankton in these lakes was also lower than that found in eutrophic or hypertrophic shallow lakes (Wang et al., 2007a). Such a finding is in accordance with the conclusion of Arcifa (1984). In the 13 lakes, the crustacean biomass showed a weak correlation with the trophic indicators. Cladocerans did not show significant correlations with the trophic indicators, which may be attributed to the unfeasible food web and predation pressure exerted by fishes and invertebrates (Amarasinghe et al., 1997). Our results suggest that deep water refuges for crustacean zooplankton are not favorable for the control of phytoplankton by large-bodied cladocerans, because small cladocerans, such as Ceriodaphnia, and large calanoids also had a high biomass in these lakes. These results also support the conclusion that top-down control 
Table 4. Summary of CCA analysis for the first two axes between environmental factors and species as well as lakes.

\begin{tabular}{|c|c|c|c|c|}
\hline \multirow[b]{2}{*}{ Axes } & \multicolumn{2}{|c|}{ Species } & \multicolumn{2}{|c|}{ Lakes } \\
\hline & 1 & 2 & 1 & 2 \\
\hline Eigenvalues & 0.438 & 0.399 & 0.423 & 0.399 \\
\hline Species-environment correlations & 0.997 & 0.998 & 0.990 & 0.997 \\
\hline Cumulative percentage variance of species data & 14.0 & 26.7 & 13.5 & 26.2 \\
\hline of species-environment relation & 17.0 & 32.5 & 18.2 & 35.4 \\
\hline Sum of all eigenvalues & \multicolumn{2}{|c|}{3.135} & \multicolumn{2}{|c|}{3.315} \\
\hline Sum of all canonical eigenvalues & \multicolumn{2}{|c|}{2.573} & \multicolumn{2}{|c|}{2.322} \\
\hline Variance explained & \multicolumn{2}{|c|}{$82.1 \%$} & \multicolumn{2}{|c|}{$70.0 \%$} \\
\hline
\end{tabular}
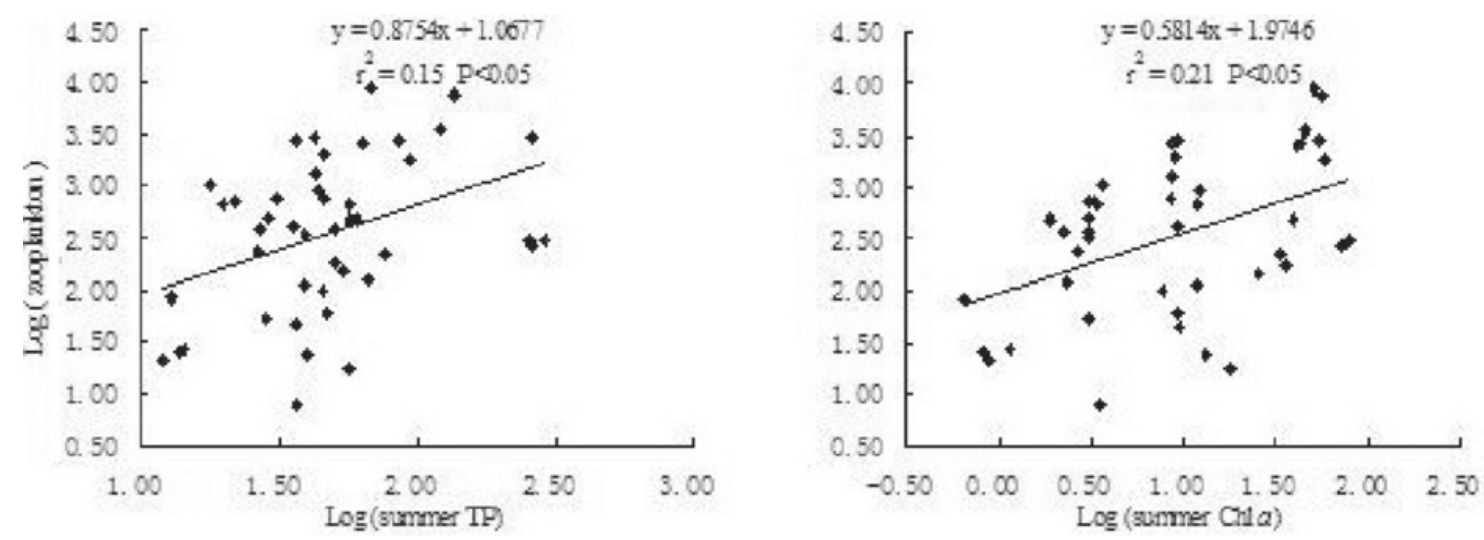

Fig. 4. Relationships between zooplankton biomass and trophic state $\left(\mu \mathrm{g} . \mathrm{L}^{-1}\right), n=41$.
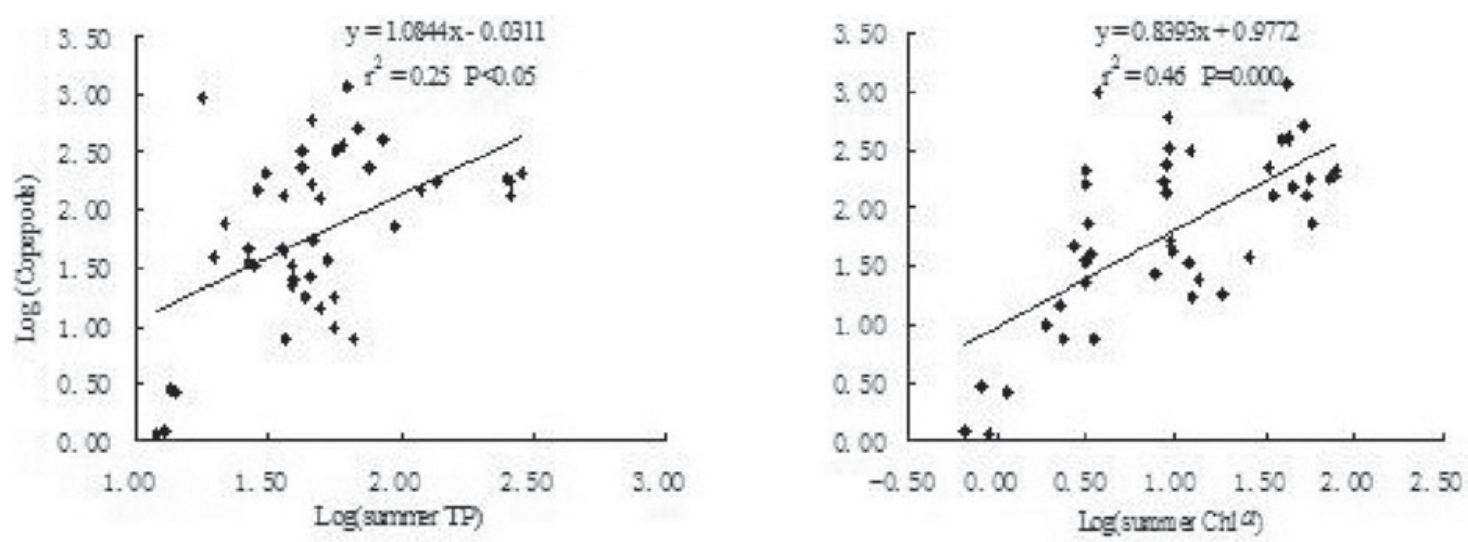

Fig. 5. Relationships between copepod biomass and trophic state $\left(\mu \mathrm{g} . \mathrm{L}^{-1}\right), n=41$.
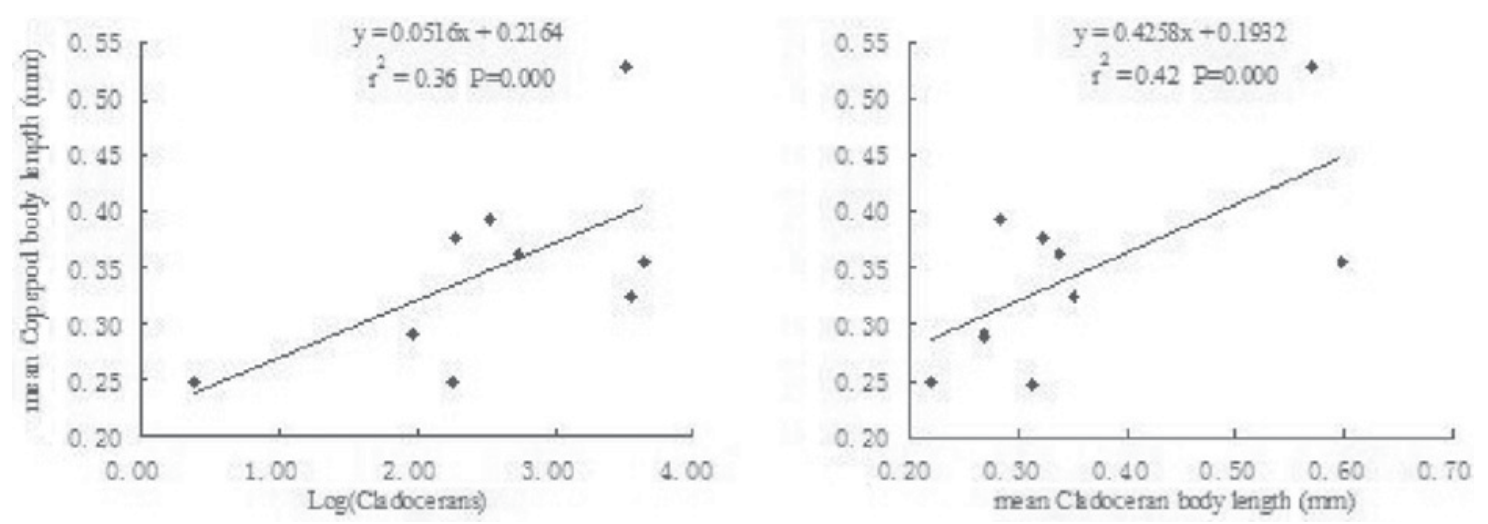

Fig. 6. Relationships between mean copepod body length $(\mathrm{mm})$, cladoceran biomass $\left(\mu \mathrm{g} . \mathrm{L}^{-1}\right)$, and mean cladoceran body length (mm), $n=15$. 

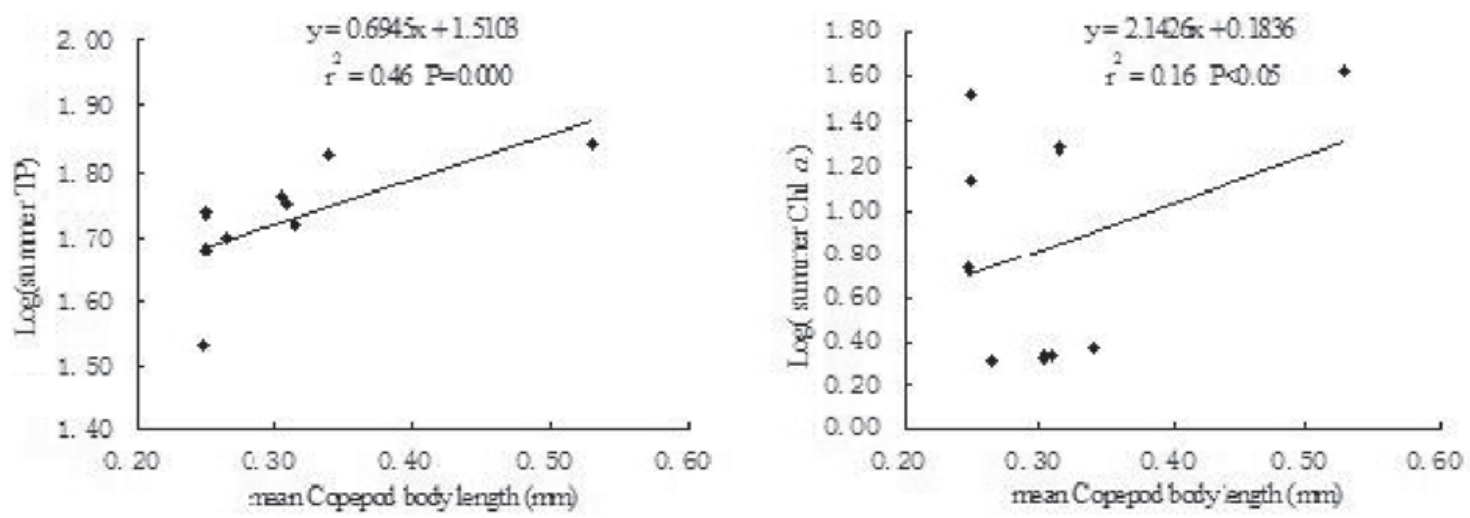

Fig. 7. Relationships between mean copepod body length, biomass, and trophic state $\left(\mu \mathrm{g} . \mathrm{L}^{-1}\right), n=15$.

Table 5. Coefficients of the Pearson correlation between crustacean biomass and water quality indicators in the two groups of lakes. The data were $\log$ transformed. $* * P<0.001, * P<0.05$. TB $=$ total crustacean biomass, the sum of cladocerans and copepods.

\begin{tabular}{|c|c|c|c|c|c|c|}
\hline & \multicolumn{3}{|c|}{ Chl $a$} & \multicolumn{3}{|c|}{$\mathrm{SD}$} \\
\hline & 1 & 2 & Total & 1 & 2 & Total \\
\hline$\overline{\mathrm{TB}}$ & 0.033 & $0.221^{*}$ & $0.415^{*}$ & $-0.242 *$ & -0.084 & $-0.515^{* *}$ \\
\hline Cladocerans & 0.007 & 0.085 & 0.033 & -0.175 & -0.180 & -0.180 \\
\hline Copepods & 0.106 & $0.910 * *$ & $0.431 *$ & -0.175 & $-0.699 * *$ & $-0.725^{* *}$ \\
\hline
\end{tabular}

on phytoplankton is not easily achieved in deep lakes or reservoirs (Benndorf, 1987; Benndorf et al., 2002).

Differing from the conclusion that copepods have strong impact on the structure of phytoplankton (e.g., Sommer et al., 2001), some researchers have found that a high proportion of copepods in the crustacean zooplankton community had a negative influence on the control of phytoplankton biomass and water quality in low-productivity lakes (Benndorf et al., 2000). In the present study, the pooled biomass of crustacean copepods showed significant relationships with trophic indicators such as chlorophyll $a$ and TP in all 13 lakes, while size structure only exhibited a relationship with chlorophyll $a$ and TP in Lake Group II. Lakes in Group II were mainly mesotrophic or slightly eutrophic. Therefore, high macrozooplankton biomass possibly reduced phytoplankton biomass and improved water quality in these lakes. In these lakes, cladoceran biomass and size structure were only positively related to the biomass and size structure of copepods and showed no significant correlation with water quality indicators. Earlier studies suggest that herbivorous calanoid copepods can exert little influence on phytoplankton biomasses due to their low overall biomasses, slow growth and low metabolic rates (Mehner et al., 2008). An increase of cyclopoid copepods would result in great mortality of herbivorous zooplankton and have a negative influence on the control of phytoplankton biomass (Blumenshine and Hambright, 2003). The increase of copepod biomass and size structure would result in the increase of inedible algae and a change of phytoplankton community (Zhang et al., 2005). The significant relationship between chlorophyll $a$ concentrations and copepods was also suggested by Kasprzak and Koschel (2000).
In accordance with predation by planktivorous fish shifting zooplankton size from large to small in eutrophic and hypertrophic shallow lakes (e.g., Slusarczyk, 1997; Yang et al., 1999; Radke and Kahl, 2002; Xie and $\mathrm{Wu}, 2002$ ), our studies demonstrated an increase of copepod biomass and size structure caused by an invasion of planktivorous fish. This alleviated the suppression of phytoplankton and resulted in a decrease in water quality.

\section{The ecological consequences of exotic fish to the lake ecosystem}

Most studies about the introduction of exotic fish are concerned with the extinction of endemic fish species (Xie and Chen, 2001). Little is known about the changes of zooplankton or phytoplankton communities after invasion by exotic fish (Zhang et al., 2005). Previous studies have suggested that the predation of exotic fish would result in an increase in the proportion of copepods in the crustacean zooplankton community (Qin et al., 2007), and an increase of copepod size structure (Liu, 2001). Zhang et al. (2005) found that invasion of $N$. taihuensis had led to a change of the dominant herbivorous zooplankton from small to large calanoids. This has increased the grazing pressure on small edible algae (e.g. Chroomonas sp.) and indirectly favored the development of the inedible filamentous Mougeotia in Fuxian Lake. Our results for Lake Group II show significant relationships between chlorophyll $a$ concentrations and the biomass and size structure of copepods in the zooplankton community in accordance with a suggestion proposed by Kasprzak and 
Koschel (2000). Currie et al. (1999) found that the presence of planktivorous fish also resulted in a significant relationship between copepods and cladocerans. Our results supply more comprehensive evidence to support the idea that copepods were more resistant to the predation of planktivorous fish (Schulz et al., 2003; Iglesias et al., 2008) and the predation of planktivorous fish on cladocerans would result in a decrease of water quality (Benndorf et al., 2002; Radke and Kahl, 2002). Therefore, invasion of exotic fish and consistent high production of these fish in lakes of Yunnan-Guizhou plateau have a negative effect on water quality.

In the present study, there is no consistent correlation between chlorophyll $a$ and cladoceran biomass or size structure. This suggests that there is little control of phytoplankton biomass by macrozooplankton, which is consistent with findings in subtropical lakes (Havens et al., 2000; Wang et al., 2007a). It also suggests that phytoplankton biomass in the 13 lakes was controlled by bottom-up, rather than top-down forces. The invasion of exotic planktivorous fish had a negative effect on water quality. In previous studies, lakes stocked with amounts of copepods, and low nutrient are usually associated with planktivorous fish (e.g., Benndorf et al., 2000; Mehner et al., 2008). Other study had also provided evidence supporting the above conclusion that the increase of copepod biomass or size structure, caused by the predation of planktivorous fish, had a negative effect on phytoplankton control and water quality (Blumenshine and Hambright, 2003).

Acknowledgements. The authors would like to thank Dr. Y.D. Cui of the Institute of Hydrobiology, Chinese Academy of Sciences, for his assistance in the laboratory work. We also thank Dr. J.H. Jiang and anonymous reviewers for their useful comments. This work was supported by a fund from Nanjing Institute of Geography and Limnology, Chinese Academy of Sciences and the Special Project titled "Investigation of water quality, water storage and biologic resource in Chinese lakes" (2006FY110600).

\section{References}

Amarasinghe P.B., Vijverberg J. and Boersma M., 1997. Production biology of copepods and cladocerans in three south-east Sri Lankan low-land reservoirs and its composition to other tropical freshwater bodies. Hydrobiologia, 350, 145-162.

Arcifa M.S., 1984. Zooplankton composition of ten reservoirs in southern Brazil. Hydrobiologia, 113, 137-145.

Attayde J.L. and Bozelli R.L., 1998. Assessing the indicator properties of zooplankton assemblages to disturbance gradients by canonical correspondence analysis. Can. J. Fish. Aquat. Sci., 55, 1789-1797.

Auer B., Elzer U. and Arunt H., 2004. Comparison of pelagic food webs in lakes along a trophic gradient and with seasonal aspects: Influence of resource and predation. J. Plankton Res., 26, 6, 697-709.
Benndorf J., 1987. Food web manipulation without nutrient control: A useful strategy in lake restoration? Schweiz. Z. Hydrol., 49, 237-248.

Benndorf J., Wissel B., Sell A.F., Hornig U., Pitter P. and Bing W., 2000. Food web manipulation by extreme enhancement of piscivory: an invertebrate predator compensates for the effects of planktivorous fish on a plankton community. Limnologica, 30, 235-245.

Benndorf J., Bing W., Koop J. and Neubauer I., 2002. Top-down control of phytoplankton: The role of time scale, lake depth and trophic state. Freshwat. Biol., 47, 2282-2295.

Blumenshine S.C. and Hambright K.D., 2003. Top-down control in pelagic systems: A role for invertebrate predation. Hydrobiologia, 491, 347-356.

Brooks J.L. and Dodson S.I., 1965. Predation, body size, and composition of plankton. Science, 150, 28-35.

Carpenter S.R., Kitchell J. and Hodgson J.R., 1985. Cascading trophic interactions and lake productivity. BioScience, 35, 10, 634-638.

Chiang S.C. and Du N.S., 1979. Fauna Sinica, Crustacea, freshwater Cladocera; Beijing: Science Press, Academia Sinica.

Currie D.J., Christie P.D. and Chapleau F., 1999. Assessing the strength of top-down influences on plankton abundance in unmanipulated lakes. Can. J. Fish. Aquat. Sci., 56, 427-436.

Elser J.J. and Goldman C.R., 1991. Zooplankton effects on phytoplankton in lakes of contrasting trophic status. Limnol. Oceanogr., 36, 1, 64-90.

Gulati R.D., 1990. Zooplankton structure in the Loosdrecht lakes in relation to trophic status and recent restoration measures. Hydrobiologia, 191, 173-188.

Hairston N.G., Smith F.E. and Slobodkin L.B., 1960. Community structure, population control, and competition. Am. Nat., 94, 421-425.

Havens K.E., 2002. Zooplankton structure and potential food web interactions in the plankton of a subtropical chain-oflakes. Sci. World J., 2, 926-942.

Havens K.E., East T.L., Marcus J., Essex P., Bolan B., Raymond S. and Beaver J.R., 2000. Dynamics of the exotic Daphnia lumholtzii and native macro-zooplankton in a subtropical chain-of-lakes in Florida, USA. Freshwat. Biol., $45,21-32$.

Huang X.F., 1999. Survey, observation and analysis of lake ecology; Beijing: Standards Press of China.

Iglesias C., Mazzeo N., Goyenola G., Fosalba C., Mello F.T.D., García S. and Jeppesen E., 2008. Field and experimental evidence of the effect of Jenynsia multidentata, a small omnivorous-planktivorous fish, on the size distribution of zooplankton in subtropical lakes. Freshwat. Biol., 53, 17971807.

Kasprzak P. and Koschel R., 2000. Lake trophic state, community structure and biomass of crustacean plankton. Verh. Int. Ver. Limnol., 27, 773-777.

Liu Z.W., 2001.The introduction of icefish, Neosalanx taihuensis Chen in China with several reference to the subtropical lakes of Yunnan Plateau (southwest China). Ver. Int. Ver. Limnol., $27,3877-3880$.

Mazumder A., 1994. Phosphorus-chlorophyll relationship under contrasting zooplankton community structure: potential mechanisms. Can. J. Fish. Aquat. Sci., 51, 401-407.

McCauley E. and Kalff J., 1981. Empirical relationships between phytoplankton and zooplankton biomass in lakes. Can. J. Fish. Aquat. Sci., 38, 458-463. 
McQueen D.J., Post J.R. and Mills E.L., 1986. Trophic relationships in freshwater pelagic ecosystems. Can. J. Fish. Aquat. Sci., 43, 1571-1581.

Mehner T., Padisak J., Kasprzak P., Koschel R. and Krienitz L., 2008. A test of food web hypotheses by exploring time series of fish, zooplankton and phytoplankton in an oligo-mesotrophic lake. Limnologica, 38, 179-188.

Pace M.L., 1986. An empirical analysis of zooplankton community size structure across lake trophic gradients. Limnol. Oceanogr., 31, 45-55.

Patalas K., 1971. Crustacean plankton communities in forty-five lakes in the Experimental Lakes Area, northwestern Ontario. J. Fish. Res. Boar. Can., 28, 231-244.

Pinto-Coelho R.P., Pinel-Alloul B.P., Méthot G. and Havens K.E., 2005. Crustacean zooplankton in lakes and reservoirs of temperate and tropical regions: Variation with trophic status. Can. J. Fish. Aquat. Sci., 62, 2, 348-361.

Qin J.H., Xu J. and Xie P., 2007. Diet overlap between the endemic fish Anabarilius grahami (Cyprinidae) and the exotic noodlefish Neosalanx taihuensis (Salangidae) in Lake Fuxian, China. J. Freshw. Ecol., 22, 3, 365-370.

Radke R. and Kahl U., 2002. Effects of a filter-feeding fish [silver carp, Hypophthalmichthys molitrix (Val.)] on phyto- and zooplankton in a mesotrophic reservoir: Results from an enclosure experiment. Freshwat. Biol., 47, 2337-2344.

Schulz M., Kasprzak P., Anwand K. and Mehner T., 2003. Diet composition and food preference of vendace (Coregonus albula (L.)) in response to seasonal zooplankton succession in Lake Stechlin. Arch. Hydrobiol. Special Issues Adv. Limnol., 58, 215-226.

Shapiro J., Lamarra V. and Lynch M., 1975. Biomanipulation: an ecosystem approach to lake restoration. In: Brezonik R.L. and Fox J.L. (eds.), Water quality management through biological control, University of Florida, Gainesville, Report No. ENV-07-75-1, 85-96.

Shen J.R., 1979. Fauna Sinica, Crustacea, freshwater Copepoda; Beijing: Science Press, Academia Sinica.

Slusarczyk M., 1997. Impact of fish predation on a small-bodied cladoceran: Limitation or stimulation? Hydrobiologia, 342/ 343, 215-221.

Sommer U., Gliwicz Z.M., Lampert W. and Duncan A., 1986. The PEG-model of seasonal succession of planktonic events in freshwaters. Arch. Hydrobiol., 106, 422-477.

Sommer U., Sommer F., Santer B., Jamieson C., Boersma M., Becker C. and Hansen T., 2001. Complementary impact of copepods and cladocerans on phytoplankton. Ecol. Lett., 4, 545-550.
Stemberger R.S. and Miller K., 2003. Cladoceran body length and Secchi disk transparency in northeastern U.S. lakes. Can. J. Fish. Aquat. Sci., 60, 1477-1486.

Swadling K.M., Pienitz R. and Nogrady T., 2000. Zooplankton community composition of lakes in the Yukon and Northwest Territories (Canada): Relationship to physical and chemical limnology. Hydrobiologia, 431, 211-224.

Taylor W.D. and Carter J.C.H., 1997. Zooplankton size and its relationship to trophic status in deep Ontario lakes. Can. J. Fish. Aquat. Sci., 54, 2691-2699.

Ter Braak C.J.F., 2004. Biometris - quantitative methods in the life and earth sciences, Plant Research International, Wageningen University and Research Centre, The Netherlands.

Tessier A.J. and Horwitz R.J., 1990. Influence of water chemistry on size structure of zooplankton assemblages. Can. J. Fish. Aquat. Sci., 47, 1937-1943.

Wang S., Xie P., Wu S. and Wang H., 2007a. Crustacean zooplankton size structure in aquaculture lakes: Is larger size structure always associated with higher grazing pressure? Hydrobiologia, 575, 203-209.

Wang S., Xie P., Wu S. and Wu A., 2007b. Crustacean zooplankton distribution patterns and their biomass as related to trophic indicators of 29 shallow subtropical lakes. Limnologica, 37, 242-249.

Wissel B., Freier K., Müller B., Koop J. and Benndorf J., 2000. Moderate planktivorous fish biomass stabilizes biomanipulation by suppressing large invertebrate predators of Daphnia. Arch. Hydrobiol., 149, 177-192.

Xie P. and Chen Y.Y., 2001. Invasive carp in China's plateau. Science, 294, 999-1000.

Xie P. and Wu L., 2002. Enhancement of Moina micrura by the filter-feeding silver and bighead carps in a subtropical Chinese lake. Arch. Hydrobiol., 154, 2, 327-340.

Yang Y.F., Huang X.F. and Liu J.K., 1999. Long-term changes in crustacean zooplankton and water quality in a shallow, eutrophic Chinese lake densely stocked with fish. Hydrobiologia, 391, 195-203.

Zhang X., Xie P., Hao L., Chen F.Z., Li Y.L., Li S.X., Guo N.C. and Qin J.H., 2005. Present status and changes of the phytoplankton community after invasion of Neosalanx tailhuensis since 1982 in a deep oligotrophic plateau lake, Lake Fuxian in the subtropical China. J. Environ. Sci., 17, 3, 389-394.

Zhuang Y.L., Feng Z.H. and Li J.H., 1996. Study on the ecological reproduction of Neosalanx taihuensis in Yunnan plateau. J. Hydroecol., 83, 16-20. 